\title{
Modos de vida e modos de habitar na moradia autoconstruída
}

\author{
Maressa Fonseca e Souza, Ítalo Itamar Caixeiro Stephan, \\ Aline Werneck Barbosa de Carvalho*
}

Resumo Pretende-se refletir sobre a autoconstrução residencial realizada pela população de baixa renda a partir da análise das relações entre a conformação dos espaços domésticos e os modos de vida e modos de habitar dos moradores. O estudo apresentado aponta uma continuidade de referências rurais nas residências avaliadas e a presença de modos de vida e modos de habitar híbridos, constatando-se a relevante influência das condições socioeconômicas. Observou-se o elevado número de intervenções, o desenvolvimento de atividades produtivas, coabitação nos terrenos, importância conferida à dimensão temporal no processo de apropriação espacial e dificuldades técnicas no planejamento e no processo construtivo.

Palavras-chave: modos de vida, modos de habitar, autoconstrução.

\section{Ways of life and ways of inhabiting in self-builted housing}

\begin{abstract}
The aim is to reflect on self-built housing carried out by the low-income population, based on the analysis of the relations between the conformation of the domestic spaces and the ways of living and the ways of inhabiting. There is a continuity of rural references in evaluated houses, hybrids ways of life and inhabiting and a relevant influence of socioeconomic conditions. It was observed the high number of interventions, the development of productive activities, cohabitation in the lands, the importance of temporal dimension in the process of spatial appropriation and technical difficulties in planning and constructive process.
\end{abstract}

Key words: ways of life, ways of inhabiting, self-builted housing.

\section{Modos de vida y modos de habitar en la vivienda autoconstruida}

Resumen Se pretende reflexionar sobre la autoconstrucción residencial realizada por la población de bajos ingresos a partir del análisis de las relaciones entre la conformación de los espacios domésticos y los modos de vida y modos de habitar de los moradores. El estudio apunta a una continuación de las referencias rurales, la presencia de estilos de vida y formas de vivir híbridas, constatando la influencia de las condiciones socioeconómicas. Se observó el elevado número de intervenciones, el desarrollo de actividades productivas, la cohabitación en los terrenos, la importancia conferida a la dimensión temporal en el proceso de apropiación espacial y dificultades técnicas en el proceso constructivo.

Palavras clave: modos de vida, modos de habitar, autoconstrucción. 
* Maressa Fonseca e Souza é Arquiteta e Urbanista, doutoranda no Programa de Pós-graduação em Economia Doméstica da Universidade Federal de Viçosa (UFV) - ORCID: <http://orcid.org/00000001-8197-4728>; Ítalo Itamar Caixeiro Stephan é Arquiteto e Urbanista, professor associado do Departamento de Arquitetura e Urbanismo da Universidade Federal de Viçosa (UFV) - ORCID: <http://orcid.org/0000-00032893-7906>; Aline Werneck Barbosa de Carvalho é Engenheira Arquiteta, professora aposentada do Departamento de Arquitetura e Urbanismo da Universidade Federal de Viçosa - ORCID: $<$ http://orcid.org/0000-00028215-7663>

${ }^{1}$ Neste trabalho, o termo utilizado para se referir a habitação destinada para a população de menor rendimento financeiro será Habitação de Interesse Social, termo primeiramente utilizado pelo extinto Banco Nacional de Habitação (BNH).
Este artigo tem como objetivo refletir sobre a prática da autoconstrução residencial realizada pela população de baixa renda a partir da análise das relações entre a conformação dos espaços domésticos autoconstruídos e os modos de vida e modos de habitar de seus moradores, tendo como foco moradias localizadas na cidade de Viçosa, no interior de Minas Gerais.

Em anos recentes, observa-se que os estudos que têm tido protagonismo dentro da temática da habitação de interesse social (HIS) vêm discorrendo sobre temas como as políticas públicas voltadas para habitação, o projeto arquitetônico e as relações entre habitação e planejamento urbano (ABREU et al., 2015). A partir de 2009, após a criação do Programa Minha Casa Minha Vida (PMCMV) observa-se o desenvolvimento de pesquisas sobre os impactos da implantação de conjuntos habitacionais no tecido urbano (CARDOSO, 2013), processos de autogestão habitacional (LAGO, 2012), avaliação da qualidade ambiental em empreendimentos habitacionais (VILLA, ORNSTEIN, 2013), dentre outros. Pode-se dizer que são escassas as abordagens que se aproximem da unidade habitacional e dos moradores, no sentido de compreender seus modos de vida e refletir sobre sua influência no fazer arquitetônico.

Nesse sentido, a pesquisa apresentada buscou realizar uma abordagem arquitetônica e sociológica, aproximando-se dos usuários para identificar suas aspirações, valores, imaginários e trajetórias, as quais, acredita-se, influenciam tanto na conformação do espaço doméstico quanto na satisfação dos moradores com a residência. Sendo assim, procurou-se identificar o modo de vida dos moradores e a forma como concebem a moradia em termos espaciais, construtivos e simbólicos, além de descrever as tipologias habitacionais e as mudanças realizadas ao longo do tempo. Buscou-se também compreender os limites entre a conformação da residência como expressão do modo de vida e como única possibilidade econômica de acesso à moradia. Isto visando contribuir para o processo de projeto de HIS, no sentido de apontar soluções mais condizentes com as necessidades habitacionais da população atendida.

Com a finalidade de realizar uma reflexão acerca dos resultados encontrados, o artigo se encontra estruturado em três partes. Primeiramente foi feita uma breve discussão sobre os temas enfatizados no estudo, sendo eles modos de vida, modos de habitar e autoconstrução residencial. Na segunda parte, foi realizada a descrição do percurso metodológico proposto e, na terceira, realizou-se uma reflexão sobre a influência dos modos de vida e modos de habitar no espaço doméstico autoconstruído a partir do objeto empírico: residências autoconstruídas localizadas nos bairros Nova Viçosa e Posses, na cidade de Viçosa - MG.

\section{Modos de vida, modos de habitar e autoconstrução}

Com o objetivo de se compreender a origem do conceito de "modos de vida" foi necessário recorrer a disciplinas distintas, principalmente no campo das ciências sociais. 
As noções sobre o tema permearam disciplinas como a Antropologia, a Geografia e a Sociologia, contudo, autores concordam que foi nesta última que o tema possuiu maior ênfase, desenvolvendo-se juntamente com as origens da própria disciplina, no século XIX, quando o pensamento iluminista, a Revolução Industrial e o crescente processo de urbanização levaram a transformações significativas na vida em sociedade (LOBO, 1992; GUERRA, 1993; NABARRO, 2014).

De Marx (1818-1883) e Engels (1820-1895) com as análises das condições de vida da classe trabalhadora, a Louis Wirth (1897-1952), em suas observações sobre as mudanças nas relações sociais no meio urbano, o estudo dos modos de vida se fez presente. No século XX, cresceu o interesse pela cotidianidade tendo em vista as mudanças trazidas pelos avanços tecnológicos e suas influências em sociabilidades, práticas de trabalho e formas de organização do espaço urbano. Segundo Guerra (1993), o conceito de modos vida foi muito criticado na Sociologia, devido à sua abrangência e às dificuldades de se articular o papel do objetivo e do subjetivo nas práticas sociais. Esta autora propôs que as noções de imaginários, racionalidades, identidades (individual e social) e projetos de vida seriam relevantes para a compreensão contemporânea dos modos de vida.

Em busca de um conceito operacional para esta pesquisa, tendo em vista as fontes teóricas consultadas durante o estudo, compreendeu-se os modos de vida como a maneira como as pessoas vivem, influenciada por fatores externos e internos ao indivíduo. Os modos de vida estariam baseados no conjunto de experiências que conformam as visões de mundo das pessoas (identidade individual e social), influenciados pela vida familiar (trajetória e composição familiar) e pelas práticas sociais (práticas de trabalho e padrões econômicos). Tendo em vista o estudo do ambiente doméstico, observou-se que estas dimensões se revelam nos modos de habitar das pessoas, seja na conformação dos espaços ou de seus elementos constituintes (mobiliários, objetos decorativos e de recordação, etc.).

Os modos de habitar foram compreendidos dentro de uma discussão sobre o sentido do habitar, relacionado a aspectos psicológicos, a sentimentos de pertencimento e segurança emocional. De acordo com Elali e Pinheiro (2013), os estudos da Psicologia Ambiental contribuem para o entendimento do significado do habitar quanto a aspectos culturais, temporais e as relações afetivas de uso e apropriação do espaço. Pode-se afirmar que os aspectos culturais estão diretamente relacionados aos modos de vida, já os temporais se relacionam com os ciclos de vida dos moradores, uma vez que na habitação se manifestam modos de dimensionar e contabilizar o tempo. O uso dos espaços corresponde a suas funcionalidades enquanto a apropriação consiste em dotar os espaços de significados individuais e sociais, gerando vínculos com os lugares (VIDAL, POL, 2005).

Segundo Pereira (2012), os modos de habitar podem ser compreendidos pelas relações práticas e simbólicas estabelecidas entre as pessoas e suas casas, analisadas através do tempo de permanência nas mesmas, no apego que desperta nos moradores e nas práticas ali desenvolvidas. Sendo assim, compreendeu-se os modos de habitar a partir de três dimensões principais, sejam elas, prática (uso dos espaços), simbólica (apropriação, demarcação territorial e privacidade) e temporal (mudanças de uso, reformas e ampliações). 
1 Parecer n० 1.004.692, de 10/04/2015.

Figura 1: Localização dos bairros Nova Viçosa e Posses, em Viçosa - MG. Fonte: Modificada pela autora a partir de Google Maps, 2016.
Por se tratar da autoconstrução residencial, apesar dos aspectos econômicos, acredita-se que não se pode entendê-la como resultado apenas de precariedade financeira. Segundo Nascimento (2011), a autoconstrução se vincula à maneira como práticas cotidianas e da realidade socioeconômica se estabelecem, em um processo carregado de valores que se manifestam no ambiente e que, somado ao processo de habitar, conferem às construções um real sentido de moradia. Como muitos autoconstrutores são os próprio moradores, acredita-se que a moradia autoconstruída expresse e materialize valores específicos.

\section{Percurso metodológico}

Por seu caráter qualitativo, a pesquisa assumiu a forma de estudos de caso. Foram selecionadas moradias autoconstruídas para a aplicação dos procedimentos, sendo utilizados métodos de coleta de dados comumente utilizados em pesquisas qualitativas e em Avaliações Pós-Ocupação do Ambiente Construído (APO), principalmente de caráter funcional e comportamental. Ressalta-se que os aspectos éticos foram respeitados de acordo com as resoluções sobre pesquisas com seres humanos, sendo o estudo aprovado pelo Comitê de Ética em Pesquisa com Seres Humanos da Universidade Federal de Viçosa'1.

As moradias foram selecionadas a partir de dados existentes no acervo documental do Projeto Habitat - Consultório Móvel de Arquitetura, projeto de extensão universitária realizado na Universidade Federal de Viçosa (UFV) através do Departamento de Arquitetura e Urbanismo (DAU), no período de 2004 a 2014. O Projeto Habitat teve como objetivo, durante seu período de atuação, oferecer assessoria técnica gratuita para o projeto de HIS para famílias que não possuíam recursos financeiros para contratar serviços técnicos no mercado formal, nem como arcar com despesas de aprovação dos projetos junto aos órgãos competentes. As atividades do Projeto foram desenvolvidas principalmente nos bairros Nova Viçosa e Posses, em Viçosa - MG.

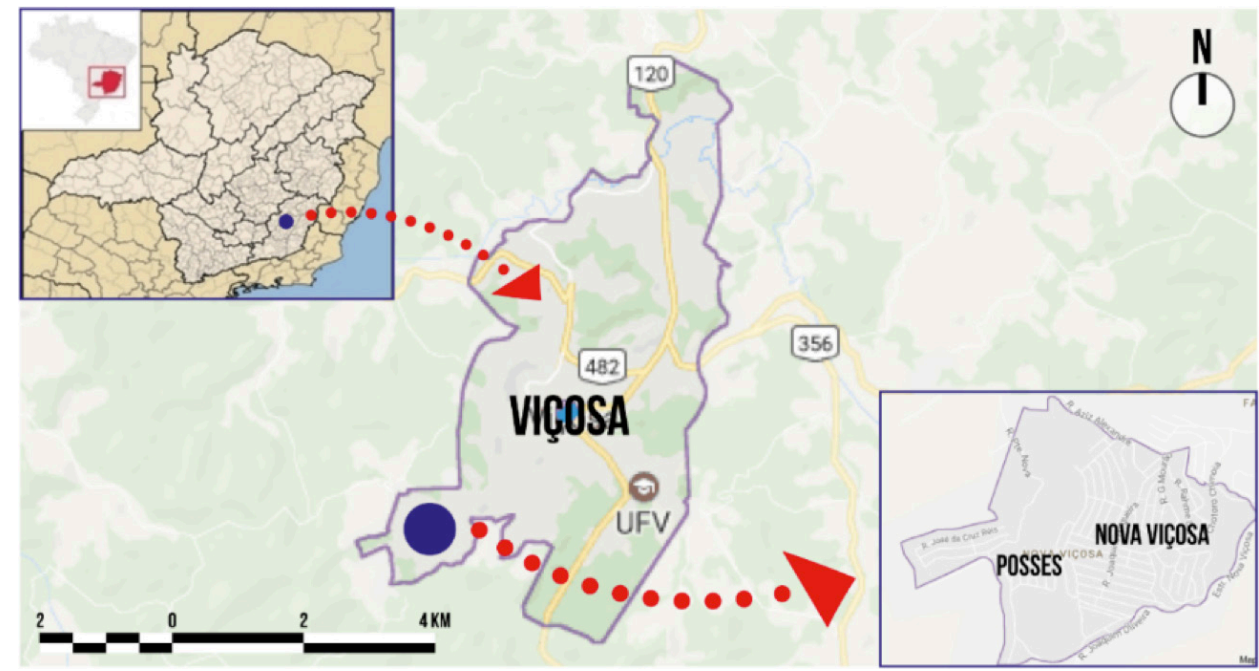


Figura 2: Vista parcial do bairro Nova Viçosa, a partir do acesso principal. Fonte: Google Street View, 2016

2 Ver documentário "Antônio Chequer: vida, política e obra". Disponível em: $<$ https://www.youtube.com/ watch?v=OXXKOWneliA>

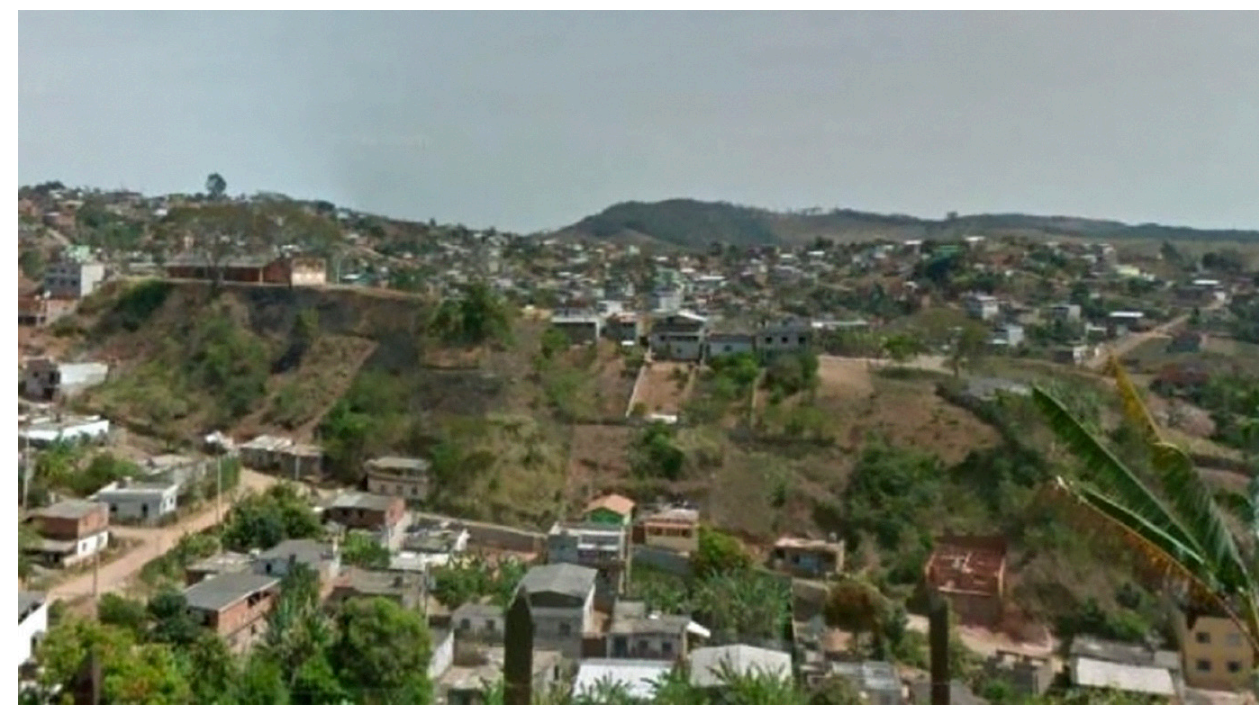

O município de Viçosa apresentou um crescimento urbano expressivo nas últimas décadas do século $X X$, principalmente devido à consolidação de sua vocação educacional pela presença da UFV. Na década de 1970, a elevação dos preços dos lotes em áreas centrais devido à demanda por moradia estudantil, levou a concentração da população de menor renda em áreas periféricas e menos servidas de infraestrutura. Nesta época foram criados diversos loteamentos na cidade, tendo como agentes de sua produção personalidades políticas atreladas a empresas do setor da construção civil. Nesse contexto surgiram os bairros Nova Viçosa e Posses, conformados a partir do parcelamento propriedades rurais pertencentes ao então prefeito da cidade, sendo os lotes vendidos a preços irrisórios ou doados ${ }^{2}$. A área loteada era caracterizada pela distância ao centro da cidade (Figura 1), relevo acidentado e ausência de infraestrutura urbana adequada. Sendo assim, os bairros nasceram como áreas desvalorizadas, onde se aglomerou uma população de menor renda oriunda de áreas rurais, de municípios próximos a Viçosa ou de outros bairros da cidade (COELHO, 2013).

Atualmente, Nova Viçosa e Posses são caracterizados como bairros com baixa densidade em relação à ocupação do solo e permanecem em condições precárias de infraestrutura urbana (Figura 2), apresentam também baixos indicadores de socioeconômicos entre sua população (CRUZ et al., 2014). A forma de provisão habitacional vem sendo realizada, em sua maioria, por meio da autoconstrução incremental, com práticas à margem da legislação urbanística e seguindo orientações feitas por pedreiros ou construtores locais (CARVALHO et al., 2013). Em 2010, apenas $28 \%$ dos lotes possuíam registro imobiliário e $84 \%$ das moradias possuíam irregularidades construtivas (DIAS et al., 2011).

Para a seleção das moradias a serem estudadas recorreu-se a uma amostragem não-aleatória por julgamento, escolhendo-se casos estimados como típicos da população objeto de estudo, tendo-se como população acessível aquela que proporcionasse acesso ao maior número de informações (BARBETTA, 2011, p.54). A 
30 passeio acompanhado consiste em um método de análise comum em APOs, que combina observação direta e entrevista, possibilitando a identificação descritiva de aspectos negativos e positivos dos ambientes analisados (RHEINGANTZ et al., 2009). Foi realizado ao percorrer todos os ambientes da residência enquanto o morador os descrevia verbalmente, sendo registrado por gravador de voz. O Mapa Afetivo consistia em uma entrevista semiestruturada combinada com a produção de fotografias de locais da residência pelo morador, com o objetivo de avaliar os níveis de apropriação do espaço, utilizando imagens e palavras para produzir sínteses ligadas aos sentimentos (BOMFIM, 2008; PINHEIRO, 2011).

Figura 3: Acessos aos bairros, principais pontos de referência e localização das moradias participantes da pesquisa. Fonte: Modificada pela autora a partir de Google Maps, 2016. seleção se limitou a famílias atendidas pelo Projeto Habitat que possuíssem registros disponíveis junto aos arquivos do projeto. Procurou-se estabelecer um limite temporal que possibilitasse o distanciamento entre a data dos atendimentos realizados e a pesquisa em questão, dessa forma seria possível identificar as modificações feitas pelos moradores ao longo do tempo.

O acervo documental do Projeto continha fichas de registro de moradores, fotografias, levantamentos arquitetônicos e projetos de reformas ou ampliações. A partir de uma listagem de clientes registrados e atendidos no período de 2004 a 2012, foram sistematizados dados de 54 famílias, divididas por anos de atendimento. Procurou-se selecionar uma família por ano, totalizando uma amostra de 6 residências (Figura 3). A seleção inicial da amostra ocorreu de acordo com a maior disponibilidade de informações existentes nos arquivos, sendo elas: ficha de registro contendo endereço e telefone dos moradores, levantamento arquitetônico da residência e levantamento fotográfico, realizados durante os acompanhamentos técnicos. Foram realizadas visitas exploratórias para identificação das residências previamente selecionadas e verificação da disponibilidade de participação dos moradores na pesquisa, procedendo-se a nova seleção em casos de indisponibilidade.

Os métodos foram selecionados de acordo com os objetivos da pesquisa, sendo a coleta de dados feita através de entrevistas semiestruturadas, seguidas da realização de passeio acompanhado (walkthrough) na residência e mapa afetivo ${ }^{3}$. Foram realizadas medições e registros fotográficos para elaboração de levantamentos arquitetônicos, bem como observação direta durante as visitas, sendo os dados registrados em anotações e diários de campo. A pesquisa de campo foi realizada entre os meses de Agosto a Dezembro de 2015.

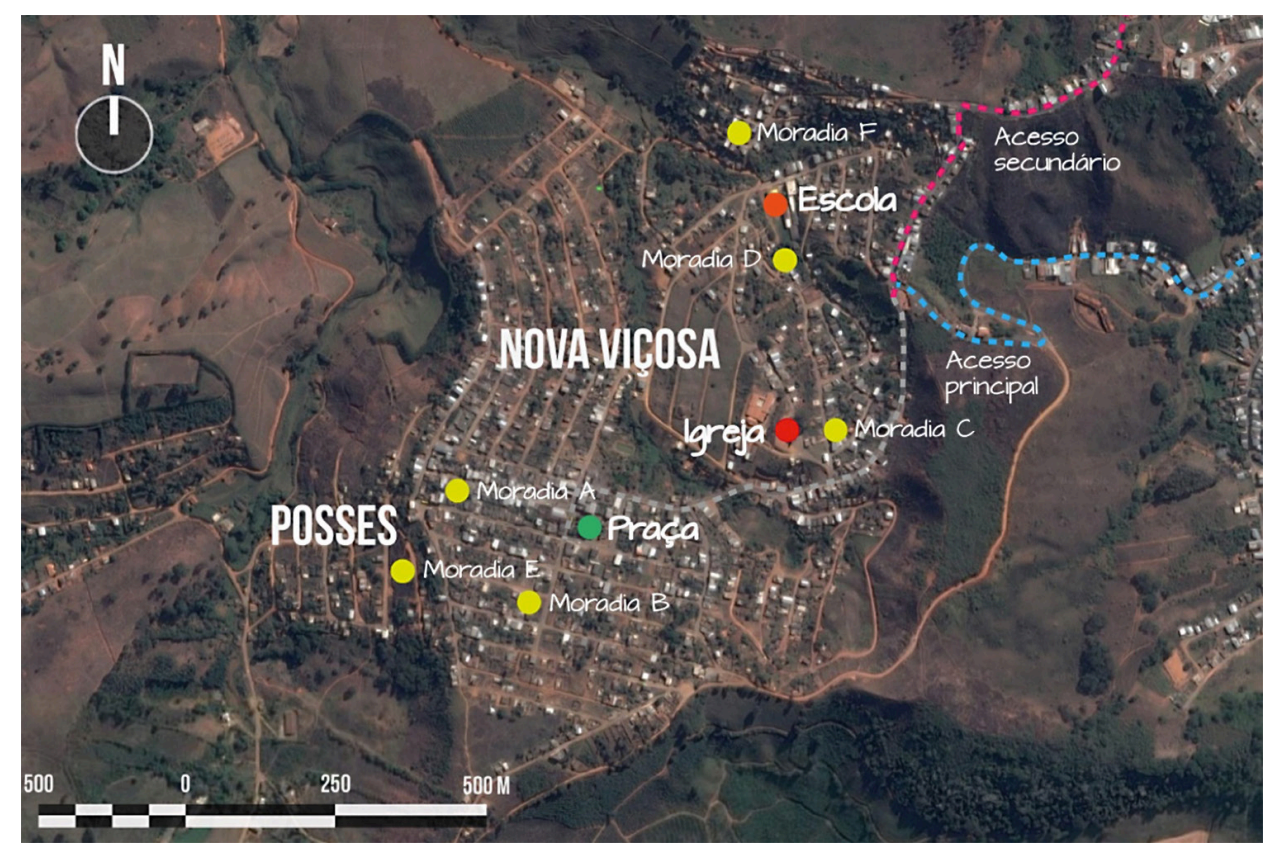




\begin{tabular}{|c|c|c|c|c|}
\hline CATEGORIA & DIMENSÕES & VARIÁVEIS & INDICADORES & MÉTODOS \\
\hline \multirow{6}{*}{ 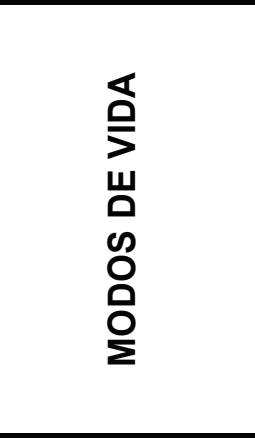 } & \multirow[b]{2}{*}{ Vida familiar } & $\begin{array}{l}\text { Composição } \\
\text { familiar }\end{array}$ & $\begin{array}{l}\text { Número de moradores; número de filhos; } \\
\text { coabitação familiar; }\end{array}$ & \multirow{6}{*}{ Entrevista } \\
\hline & & Trajetória familiar & $\begin{array}{l}\text { Origem (rural, urbana); ciclo de vida familiar; } \\
\text { trajetória habitacional; escolaridade; projeto de } \\
\text { vida (alcançado e expectativas); }\end{array}$ & \\
\hline & \multirow{2}{*}{ Práticas sociais } & $\begin{array}{l}\text { Padrões } \\
\text { econômicos }\end{array}$ & $\begin{array}{l}\text { Renda do chefe de família; renda média } \\
\text { familiar; origem da família; }\end{array}$ & \\
\hline & & Práticas de trabalho & Profissão; ocupação; & \\
\hline & \multirow{2}{*}{ Visão de mundo } & $\begin{array}{l}\text { Identidade } \\
\text { individual }\end{array}$ & $\begin{array}{l}\text { Interesses; gostos; sentimentos; } \\
\text { representações (imaginário); }\end{array}$ & \\
\hline & & Identidade social & $\begin{array}{l}\text { Pertencimento a um grupo/categoria social; } \\
\text { religião; }\end{array}$ & \\
\hline \multirow{5}{*}{ 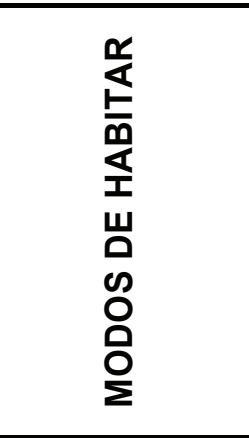 } & Dimensão prática & Uso & $\begin{array}{l}\text { Funções; sobreposição de usos; tempo de } \\
\text { permanência; equipamentos; mobiliário; }\end{array}$ & \multirow{5}{*}{$\begin{array}{l}\text { Entrevista } \\
\text { Passeio } \\
\text { Acompanhado } \\
\text { Mapa Afetivo } \\
\text { Observação } \\
\text { direta }\end{array}$} \\
\hline & \multirow{3}{*}{$\begin{array}{l}\text { Dimensão } \\
\text { simbólica }\end{array}$} & $\begin{array}{l}\text { Apropriação do } \\
\text { espaço }\end{array}$ & $\begin{array}{l}\text { Personalização e humanização; marcas } \\
\text { deixadas no espaço; objetos; disposição de } \\
\text { objetos; materiais; texturas; cores; formas; }\end{array}$ & \\
\hline & & $\begin{array}{l}\text { Demarcação } \\
\text { territorial (público/ } \\
\text { privado) }\end{array}$ & $\begin{array}{l}\text { Hierarquia dos ambientes; disposição dos } \\
\text { ambientes; setorização; }\end{array}$ & \\
\hline & & Privacidade & Muros; cercas; fechamentos fixos ou móveis; & \\
\hline & $\begin{array}{l}\text { Dimensão } \\
\text { temporal }\end{array}$ & $\begin{array}{l}\text { Temporalidade } \\
\text { (relação espaço- } \\
\text { tempo) } \\
\end{array}$ & $\begin{array}{l}\text { Mudanças de uso; reformas; ampliações; novas } \\
\text { edificações no mesmo lote; expectativas em } \\
\text { relação a casa; }\end{array}$ & \\
\hline \multirow{8}{*}{ 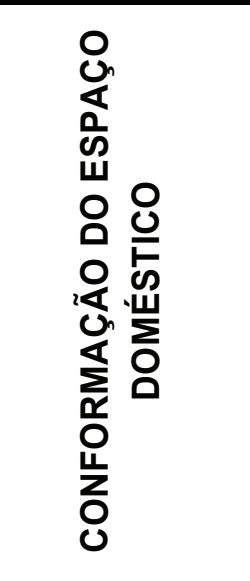 } & \multirow{3}{*}{ Terreno } & $\begin{array}{l}\text { Relação com a } \\
\text { malha urbana }\end{array}$ & $\begin{array}{l}\text { Acessos; relação casa/rua; jardins; muros; } \\
\text { quintais; }\end{array}$ & \multirow{8}{*}{$\begin{array}{l}\text { Entrevistas } \\
\text { Observação } \\
\text { direta } \\
\text { Levantamento } \\
\text { arquitetônico }\end{array}$} \\
\hline & & Implantação & Dimensões do terreno; afastamentos; & \\
\hline & & Topografia & Desníveis; acessos; & \\
\hline & \multirow{5}{*}{ Moradia } & Histórico & $\begin{array}{l}\text { Construtores; tempo de residência; reformas; } \\
\text { ampliações; }\end{array}$ & \\
\hline & & Estética & $\begin{array}{l}\text { Cores; materiais de acabamento; vãos; } \\
\text { esquadrias; cobertura; vegetação; }\end{array}$ & \\
\hline & & $\begin{array}{l}\text { Características } \\
\text { construtivas }\end{array}$ & Material de construção; acabamentos; & \\
\hline & & Arranjo funcional & $\begin{array}{l}\text { Relação, disposição e dimensões dos } \\
\text { compartimentos; relação e disposição de } \\
\text { mobiliário e equipamentos; circulação entre } \\
\text { cômodos; }\end{array}$ & \\
\hline & & $\begin{array}{l}\text { Relação interior / } \\
\text { exterior }\end{array}$ & $\begin{array}{l}\text { Relação casa/rua; relação casa/quintal ou } \\
\text { jardim; }\end{array}$ & \\
\hline
\end{tabular}

Tabela 1: Modelo de análise de acordo com as variáveis Modo de vida, Modo de habitar e Conformação do espaço doméstico. Fonte: Elaborada pela autora, 2016.

4 Segundo Rheingantz et al. (2009, p.91), a Matriz de Descobertas foi desenvolvida para registro gráfico de resultados e descobertas em APO, de modo a facilitar a leitura e compreensão dos resultados e descobertas em função do grande número ...continua próximas páginas...
Foram propostas categorias de análise de acordo com a revisão de literatura, sendo elas, Modos de Vida, Modos de Habitar e Conformação do Espaço Doméstico. A partir disso, elaborou-se um modelo de análise com dimensões, variáveis, indicadores e os métodos utilizados para sua identificação (Tabela 1).

Os áudios registrados foram transcritos e os dados foram organizados de acordo com categorias de análise propostas, associados com levantamentos arquitetônicos e registros fotográficos. Para cada um dos casos analisados foi elaborada uma Matriz de Descobertas ${ }^{4}$ contendo plantas baixas dos levantamentos arquitetônicos, representação tridimensional esquemática da residência, com a indicação temporal de reformas ou ampliações, análises sobre as plantas baixas em relação às variáveis simbólica e prática, fotografias da residência e sínteses do perfil familiar dos moradores (Figura 4). 


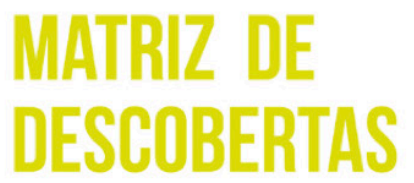

\section{MORADIAC: \\ UM SANTUÁRIO}

\section{MODO DE VIDA}

COMPOSIÇÃO FAMILAR:

Maria Gertrudes (84) Walter (enteado, 63) / Nora e neto

TRAETÓRIA:

Origem rural, familia de lavradores:

Sem instruciag formal.

PRáTICAS SOCIIIS:

Atividades religiosas e tarefas domésticas

VISÃO DE MUNDO:

Apego à religiác

TEMPO DE RESIDENCIA NOLOCAL.

26 anos

* OBSERVAC̄̄ES:

Coabitação de 3 familias no terreno.

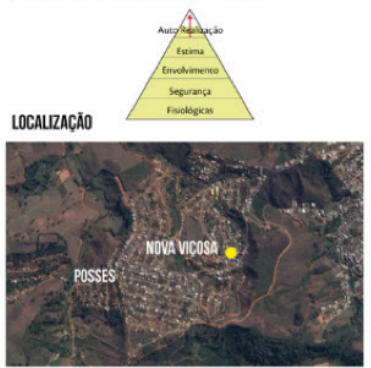

MODO DE HABITAR + CONFIGURAÇÃO ESPACIAL DIMENSÖES:

\section{SIMBÓLICA}

\section{Apropriaçáo do espaço}

- Afetividade

Privacidade
$X$ Portas fechadas

$X$ Muro/Cerca

$X$ Grades

X Fechamentos móveis

Demarcaçáo territorial
* Espaços mais valorizados pela familia

Setorizacăo:

\begin{tabular}{l} 
Social \\
Intimo \\
\hline
\end{tabular}

- Intimo
Servicos
Social + Servicos

PRÁTICA

Funçoes
Lazer
Case

- Convivio familiar / social

A Aazer refeiçóes

Preparo de refeiçóes

- Higiene

- Devoçáo / Oraçáo

- Cavar roupas
- Secar roupas

- Guardar pertences

(כ) Permanência

$\leftrightarrow \rightarrow$ Continuidade de uso do espaç

$\because$ Restriçáo de acesso

\section{TEMPORAL}

1 "Barraquinho"
2 "Casa de telha"

3 Garagem evarandas
4 Varanda dos fundos

4 Varanda dos fundos

5 Primeiro terraç

7 segundo terraç

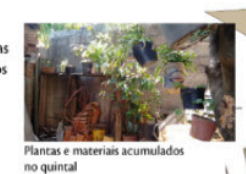

Figura 4: Matriz de descobertas elaborada para a Moradia C, como forma de síntese dos dados obtidos. Fonte: Elaborada pela autora, 2016. 
..continuação da nota 4 ..

de informações, que dificultam a organização e apresentação de resultados. Consiste em um instrumento gráfico que permite reunir e relacionar em poucas pranchas de desenho as principais descobertas em um edifício, apresentando facilidade de manuseio e visualização global, especialmente se comparada a resultados e descobertas descritos por meio de tabelas, quadros ou textos.

Tabela 2: Síntese das informações obtidas a partir da categoria "Modos de Vida". Fonte: Elaborada pela autora, 2016.

\section{As relações entre modos de vida e modos de habitar na con- formação espacial das residências autoconstruídas}

Os diferentes modos de vida das famílias se expressam através da conformação dos espaços residenciais, na forma de uso e apropriação dos mesmos pelos moradores e nas modificações realizadas ao longo do tempo nas moradias. A análise das residências evidencia que não há um padrão espacial entre as moradias autoconstruídas, de maneira que suas conformações acompanham a multiplicidade dos modos de vida e modos de habitar dos moradores, que, por sua vez, variam de acordo com sua trajetória de vida, visão de mundo e condição socioeconômica. Sendo assim, estrutura-se a análise a seguir a partir das três principais categorias enfatizadas no estudo.

\subsection{Modos de vida}

Todas as famílias possuem 10 ou mais anos de residência nas residências e a origem de metade dos moradores é rural, sendo oriundos de áreas rurais de municípios da

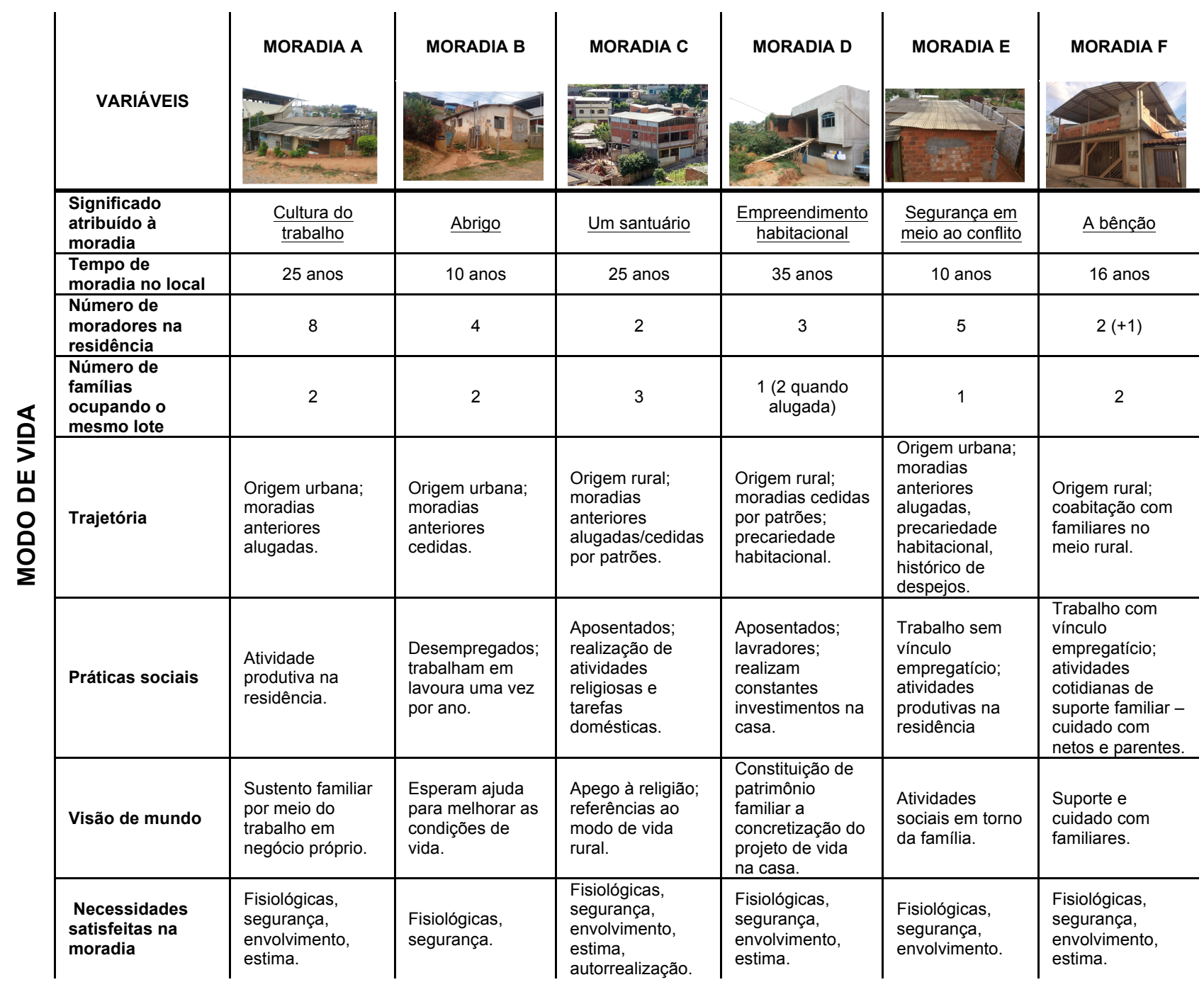


região de Viçosa; os que possuem origem urbana residiram em outros bairros da cidade. Observou-se uma continuidade de referências rurais em hábitos cotidianos dos moradores, no uso dos espaços e na conformação das residências. As referências se dão principalmente pelas formas de lidar com o preparo de alimentos, fazendo uso do fogão a lenha tanto para preparo de refeições diárias quanto para cozimentos mais longos, sendo estes localizados na parte externa e posterior à residência ou em varandas próximas à cozinha. A presença de varandas na parte posterior das casas ou varandas frontais se associa à configuração dos alpendres, comuns em moradias rurais tradicionais mineiras. Observou-se também a prática de criação de animais pela presença de galinheiros e a prática de cultivo de hortas em quintais ou em terrenos vizinhos, que se encontram desocupados.

Verificou-se que a trajetória habitacional da maioria das famílias consistiu na passagem por moradias de aluguel ou cedidas, que geralmente apresentavam condições precárias, até a autoconstrução da moradia própria, que se fez em etapas, ao longo do tempo. Percebe-se que a moradia autoconstruída reflete o desejo de superação do histórico de precariedade habitacional na trajetória de vida das famílias. A construção de cômodos amplos e as constantes ampliações afirmam a negação das privações passadas em moradias cedidas no meio rural, por exemplo, ou mesmo em moradias urbanas alugadas. Verificou-se o desejo de se superar uma trajetória habitacional insegura pela posse da casa própria em praticamente todos os casos. A moradia de aluguel é fortemente rejeitada, tanto pela insegurança representada, quanto pelo consumo de parte considerável da renda já reduzida, que poderia ser utilizada para itens mais relevantes para a subsistência das famílias. A configuração da trajetória habitacional passada coopera para a valorização da construção e da posse da casa no modo de vida dos moradores, fazendo dela a representação do ato sublimado de um projeto de vida pelo qual se lutou (PINTO, 1998).

Esta valorização da posse ocorre mesmo que as condições da moradia atual sejam precárias. Há uma constante iniciativa em se realizar reformas e ampliações nas residências, de acordo com a disponibilidade de renda. Mesmo com poucos recursos financeiros, observou-se que todas as famílias realizaram ampliações nas residências, em maior ou menor número. A valorização também é reforçada pela possibilidade de se constituir um patrimônio a ser deixado para os descendentes, procurando assegurarIhes melhores condições de vida e de habitação do que as que foram anteriormente vivenciadas pelos moradores.

Há coabitação na maioria dos terrenos, sendo eles divididos entre duas ou mais famílias de filhos dos moradores ou de parentes próximos, prática compreendida como um suporte social e econômico para as famílias de filhos ou parentes mais próximos. Destaca-se o fato de que a coabitação não ocorre com pessoas estranhas ao círculo familiar, reforçando a função da casa como apoio para a continuidade da família. Nota-se que a construção de lajes superiores ou a expectativa de sua construção representa a adição de mais um pavimento útil à residência, seja para construção de uma nova moradia ou pela possibilidade do desenvolvimento de atividades em um terraço coberto. Pode-se afirmar que construção da laje representa a superação de mais uma etapa na trajetória habitacional: a gradação da cobertura do abrigo (lona - telha de fibrocimento - laje de concreto - cobertura metálica) tende a representar a ascensão social dos moradores. 


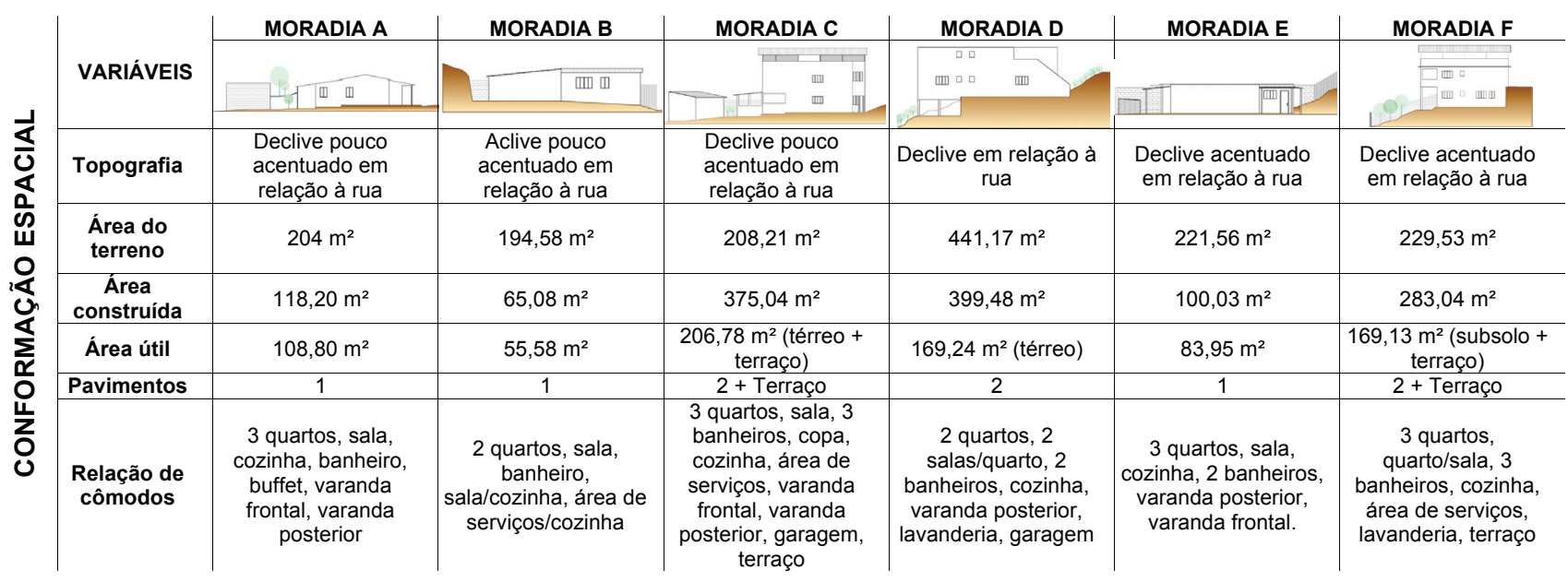

Tabela 3: Síntese das informações obtidas a partir da categoria "Conformação Espacial". Fonte: Elaborada pela autora, 2016.

\subsection{Conformação do espaço doméstico}

A maioria dos terrenos possui área aproximada de 200 metros quadrados, conforme o parcelamento realizado para a implantação dos loteamentos. A topografia local influencia na configuração das moradias localizadas abaixo do nível da rua, com acesso realizado por meio de rampas, escadas ou caminhos improvisados no talude. A configuração dos terrenos influencia na conformação espacial das residências, geralmente dispostas em sentido longitudinal, com a presença de cômodos de serviços voltados para os fundos e cômodos de uso social ou íntimo voltados para a frente do lote, ainda que isto não seja um padrão. Os fundos dos lotes geralmente conformam os quintais onde ocorrem cultivo de hortas, atividades de lazer e armazenagem de utensílios. Embora a maioria das casas possuam afastamentos laterais, em alguns casos observou-se a construção sobre as divisas, certas vezes sugerida pelos próprios pedreiros para aumentar a área útil. Uma das moradias chega a invadir um terreno vizinho, utilizando-o para sua expansão.

A área construída das residências varia entre 65 a 400 metros quadrados, sendo as áreas maiores identificadas entre as residências de moradores mais antigos. Em relação às características construtivas, notou-se a presença de casas térreas, casas com mais de um andar e com terraços cobertos, característica que se repete por toda a extensão dos bairros. Além disso, identificou-se que todas as residências passaram por alguma reforma ou ampliação. Os materiais de construção típicos são o concreto armado, alvenaria de bloco cerâmico ou bloco de concreto, telhas de fibrocimento sobre estrutura de madeira ou telhas de alumínio sobre estrutura metálica. Estes materiais são adquiridos por sua viabilidade econômica, mas refletem também um modo de construir típico da classe média, no que se refere aos materiais e técnicas construtivas empregadas.

Em algumas residências, material de refugo (telhas, portas de armários, compensados de madeira, etc.) foi utilizado como material de construção, como na vedação de cômodos ampliados ou para demarcação de limites nos terrenos; em alguns casos, tanto materiais de construção quanto de refugo foram obtidos através de doações 
ou trocas com pessoas conhecidas. Geralmente os materiais são armazenados nos terrenos ou em cômodos inacabados na construção.

Constatou-se a característica inacabada das construções, seja por obras interrompidas ou pela ausência de materiais de acabamento, principalmente reboco e pintura. Além disso, é recorrente a ausência de portas e janelas em algumas, de maneira que os moradores fazem uso de tecidos ou material de refugo para fechamento das aberturas. Isto denota não só a condição de restrições econômicas como a pouca importância conferida à privacidade por parte de algumas famílias.

Em relação aos materiais de acabamento, observou-se que determinadas superfícies possuem acabamentos e outras não, ou apenas um cômodo da residência possui acabamentos nas paredes, por exemplo. Isto demonstra o aspecto simbólico do processo de construção incremental, uma vez que não se abre mão dos acabamentos sendo os mesmos feitos aos poucos, cômodo por cômodo ou superfície por superfície dentro de um mesmo cômodo. Percebe-se, portanto, que apropriação espacial é dependente da variável temporal na moradia autoconstruída e confirmam que a etapa de finalização dos acabamentos coincide com o alcance do nível de autorrealização dos moradores em relação à casa (LEITE, 2006).

\subsection{Modos de habitar}

\section{a. Dimensão prática}

Quanto aos usos dos espaços, observou-se a presença de cômodos sem função definida e a sobreposição de atividades em quase todos os casos. Além disso são característicos os usos incoerentes ou não desejáveis de alguns cômodos, como atividades de higiene pessoal realizadas no banheiro e na cozinha, preparo de alimentos ocorrendo na cozinha e na área de serviços, e refeições realizadas na sala, quartos e no buffet.

As cozinhas são utilizadas como área de convívio social e recepção de visitas, ainda que as salas possuam esta finalidade, contudo não são tão valorizadas. O preparo de refeições é realizado nas cozinhas, bem como em varandas e quintais onde se localizam os fogões a lenha. Conforme mencionado anteriormente, a maioria das cozinhas se encontra implantada na parte posterior das construções, onde ocorre uma continuidade de uso destes espaços junto às varandas e quintais, confirmando uma tradição arraigada na concepção espacial da casa brasileira. O uso do fogão a lenha na parte externa da residência ou na varanda próxima à cozinha remete à presença das cozinhas interna e externa nas residências coloniais, referidas como "limpa" e "suja" respectivamente, esta última destinada a cozimentos mais demorados e atividades menos higiênicas (LEMOS, 1989; ALGRANTI, 1997). Pode-se considerar que o uso do fogão a lenha também está relacionado com as restrições econômicas das famílias, pois evita os gastos com a compra de gás de cozinha ou energia elétrica.

Os quintais assumem o papel de fornecer elementos para a subsistência familiar, para o desenvolvimento de atividades produtivas e estocagem de materiais. Particularmente em Nova Viçosa e Posses, a baixa densidade de ocupação dos lotes gerou vazios urbanos, dessa forma os moradores utilizam lotes vizinhos, que permanecem desocupados, como quintal de suas casas. Por não serem reivindicados pelos proprietários, os lotes 
Tabela 4: Síntese das informações obtidas a partir da categoria "Modos de Habitar - Dimensão prática". Fonte: Elaborada pela autora, 2016. acabaram sendo apropriados pelas famílias, que promoveram a construção de cercas e a manutenção dos mesmos. O uso dessas áreas remete à descrição de Algranti (1997) sobre a moradia colonial, em que identificou o aspecto funcional e econômico dos quintais, uma vez que era neles que se extraíam e se produziam recursos utilizados no dia-a-dia pelas as famílias, principalmente gêneros alimentícios.

Observou-se que ambientes como quartos e salas de estar são utilizados para lazer, entretanto as atividades se restringem a ver televisão e jogos de vídeo game, sendo que alguns moradores mais antigos tem o costume de ouvir o rádio diariamente. Em ambientes íntimos, como os quartos, observou-se a sua valorização e o tempo de permanência, sendo utilizados como locais de descanso e lazer.

\begin{tabular}{|c|c|c|c|c|c|c|c|}
\hline & VARIÁVEIS & MORADIA A & MORADIA B & MORADIA C & MORADIA D & MORADIA E & MORADIA F \\
\hline & Repouso & Quartos & Quartos & Quartos, terraço & $\begin{array}{l}\text { Quartos, } \\
\text { sala/quarto }\end{array}$ & Quartos & $\begin{array}{l}\text { Quartos, } \\
\text { quarto/sala }\end{array}$ \\
\hline & $\begin{array}{l}\text { Convívio } \\
\text { familiar e } \\
\text { social }\end{array}$ & Sala & $\begin{array}{l}\text { Sala/cozinha, } \\
\text { sala }\end{array}$ & $\begin{array}{l}\text { Sala, copa, } \\
\text { cozinha }\end{array}$ & $\begin{array}{l}\text { Cozinha, } \\
\text { sala/quarto }\end{array}$ & $\begin{array}{l}\text { Sala, quintal, } \\
\text { varanda } \\
\text { posterior }\end{array}$ & Sala, cozinha \\
\hline & Alimentação & $\begin{array}{l}\text { Cozinha, } \\
\text { varanda } \\
\text { posterior }\end{array}$ & $\begin{array}{l}\text { Sala/cozinha, } \\
\text { quintal, sala, } \\
\text { quartos }\end{array}$ & $\begin{array}{l}\text { Cozinha, copa, } \\
\text { varanda } \\
\text { posterior }\end{array}$ & Cozinha & $\begin{array}{l}\text { Cozinha, } \\
\text { varanda } \\
\text { posterior, sala }\end{array}$ & $\begin{array}{l}\text { Cozinha, } \\
\text { varanda } \\
\text { posterior }\end{array}$ \\
\hline & $\begin{array}{l}\text { Cuidados com } \\
\text { higiene e com } \\
\text { o corpo }\end{array}$ & $\begin{array}{l}\text { Banheiro, } \\
\text { cozinha, área de } \\
\text { serviço }\end{array}$ & $\begin{array}{l}\text { Banheiro, } \\
\text { cozinha }\end{array}$ & Banheiro & Banheiro & Banheiro & Banheiro \\
\hline & Lazer & Quarto, buffet & Sala, quarto & Sala, terraço & Sala/quarto & $\begin{array}{l}\text { Sala, quintal, } \\
\text { quarto }\end{array}$ & $\begin{array}{l}\text { Sala, quarto de } \\
\text { hóspedes, } \\
\text { sala/quarto }\end{array}$ \\
\hline & $\begin{array}{l}\text { Estudos ou } \\
\text { trabalho }\end{array}$ & $\begin{array}{l}\text { Quarto do casal, } \\
\text { quarto dos filhos }\end{array}$ & Sala de estar & - & Quarto da neta & Sala de estar & $\begin{array}{l}\text { Quarto de } \\
\text { hóspedes, } \\
\text { quarto de casal }\end{array}$ \\
\hline 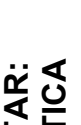 & $\begin{array}{l}\text { Cuidados com } \\
\text { vestuário }\end{array}$ & $\begin{array}{l}\text { Varanda } \\
\text { posterior, quintal }\end{array}$ & $\begin{array}{l}\text { Área de } \\
\text { serviços/cozinha } \\
\text {, quintal }\end{array}$ & $\begin{array}{l}\text { Área de } \\
\text { serviços, terraço }\end{array}$ & $\begin{array}{l}\text { Lavanderia, } \\
\text { primeiro } \\
\text { pavimento }\end{array}$ & $\begin{array}{l}\text { Área de } \\
\text { serviços, quintal }\end{array}$ & $\begin{array}{l}\text { Lavanderia, } \\
\text { varanda } \\
\text { posterior, } \\
\text { quintal, terraço }\end{array}$ \\
\hline 통 & $\begin{array}{l}\text { Guardar } \\
\text { pertences }\end{array}$ & Quartos, buffet & $\begin{array}{l}\text { Cômodo/corred } \\
\text { or }\end{array}$ & $\begin{array}{l}\text { Quartos, área } \\
\text { de serviços }\end{array}$ & $\begin{array}{l}\text { Varandas, } \\
\text { quartos, } \\
\text { sala/quarto }\end{array}$ & Quartos, sala & $\begin{array}{l}\text { Lavanderia, } \\
\text { quartos }\end{array}$ \\
\hline 岩造 & $\begin{array}{l}\text { Atividade } \\
\text { produtiva }\end{array}$ & Buffet & - & - & Terreno vizinho & Cozinha & - \\
\hline ㅇํํ 니 & $\begin{array}{l}\text { Criação de } \\
\text { animais }\end{array}$ & - & - & - & - & Quintal & - \\
\hline$\frac{\bar{\Sigma}}{\Sigma}$ & $\begin{array}{l}\text { Principais } \\
\text { mobiliários/ } \\
\text { equipamentos } \\
\text { presentes na } \\
\text { residência }\end{array}$ & $\begin{array}{l}\text { Camas, sofá, } \\
\text { guarda-roupas, } \\
\text { cadeiras, } \\
\text { armários } \\
\text { improvisados, } \\
\text { TVs, vídeo } \\
\text { game, tanque } \\
\text { automático }\end{array}$ & $\begin{array}{l}\text { Camas, sofás, } \\
\text { cadeiras, } \\
\text { estantes, } \\
\text { suporte para } \\
\text { TV, armários } \\
\text { improvisados, } \\
\text { TV, vídeo game, } \\
\text { computador } \\
\text { portátil }\end{array}$ & $\begin{array}{l}\text { Camas, sofás, } \\
\text { guarda-roupas, } \\
\text { suporte para } \\
\text { TV, TV, rádio, } \\
\text { mesa de jantar, } \\
\text { cadeiras, } \\
\text { armários de } \\
\text { cozinha, bancos } \\
\text { de madeira, } \\
\text { estantes }\end{array}$ & $\begin{array}{l}\text { Camas, sofás, } \\
\text { guarda-roupas, } \\
\text { estantes, } \\
\text { cômodas, mesa } \\
\text { de jantar, } \\
\text { armários de } \\
\text { cozinha, suporte } \\
\text { para TV, TV, } \\
\text { mesa para } \\
\text { computador, } \\
\text { computador, } \\
\text { cadeiras, } \\
\text { máquina de } \\
\text { lavar, tanque } \\
\text { automático }\end{array}$ & $\begin{array}{l}\text { Camas, sofás, } \\
\text { guarda-roupas, } \\
\text { armários } \\
\text { improvisados, } \\
\text { cômodas, } \\
\text { suporte para } \\
\text { TV, TVs, rádio, } \\
\text { armário de } \\
\text { cozinha }\end{array}$ & $\begin{array}{l}\text { Camas, sofás, } \\
\text { guarda-roupas, } \\
\text { cômoda, } \\
\text { suporte para } \\
\text { TV, TV, vídeo } \\
\text { game, mesa } \\
\text { para } \\
\text { computador, } \\
\text { computador, } \\
\text { mesa para } \\
\text { refeições e } \\
\text { bancos, armário } \\
\text { de cozinha, } \\
\text { máquina de } \\
\text { lavar }\end{array}$ \\
\hline & $\begin{array}{l}\text { Principais } \\
\text { equipamentos } \\
\text { presentes nas } \\
\text { cozinhas }\end{array}$ & $\begin{array}{l}\text { Fogão a gás, } \\
\text { geladeira, } \\
\text { liquidificador, } \\
\text { forno elétrico, } \\
\text { freezer, pia, } \\
\text { fogão a lenha } \\
\text { (externo) }\end{array}$ & $\begin{array}{l}\text { Fogão a gás, } \\
\text { tanque } \\
\text { automático, } \\
\text { geladeira, pia, } \\
\text { fogão a lenha } \\
\text { (externo) }\end{array}$ & $\begin{array}{l}\text { Fogão a gás, } \\
\text { geladeira, } \\
\text { liquidificador, } \\
\text { fogão a lenha } \\
\text { (externo) }\end{array}$ & $\begin{array}{l}\text { Fogão a gás, } \\
\text { geladeira, } \\
\text { liquidificador }\end{array}$ & $\begin{array}{l}\text { Fogão a gás, } \\
\text { geladeira, } \\
\text { batedeira, } \\
\text { liquidificador, } \\
\text { fogão a lenha } \\
\text { (externo) }\end{array}$ & $\begin{array}{l}\text { Fogão a gás, } \\
\text { geladeira, } \\
\text { liquidificador, } \\
\text { fogão a lenha } \\
\text { (externo) }\end{array}$ \\
\hline
\end{tabular}




\begin{tabular}{|c|c|c|c|c|c|c|c|}
\hline \multirow{5}{*}{ 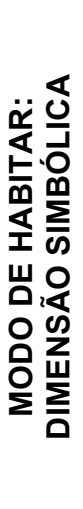 } & VARIÁVEIS & MORADIA A & MORADIA B & MORADIA C & MORADIA D & MORADIA E & MORADIA F \\
\hline & $\begin{array}{l}\text { Ambientes com } \\
\text { maior tempo de } \\
\text { permanência }\end{array}$ & $\begin{array}{l}\text { Buffet, quintal, } \\
\text { quarto }\end{array}$ & $\begin{array}{l}\text { Quartos, sala, } \\
\text { quintal }\end{array}$ & $\begin{array}{l}\text { Cozinha, quarto, } \\
\text { quintal }\end{array}$ & $\begin{array}{l}\text { Cozinha, } \\
\text { sala/quarto, } \\
\text { quarto }\end{array}$ & $\begin{array}{l}\text { Quintal, cozinha, } \\
\text { sala }\end{array}$ & $\begin{array}{l}\text { Quarto de casal, } \\
\text { quarto de } \\
\text { hóspedes }\end{array}$ \\
\hline & $\begin{array}{l}\text { Cômodos com } \\
\text { maior } \\
\text { sobreposição } \\
\text { de atividades }\end{array}$ & $\begin{array}{l}\text { Buffet, quarto } \\
\text { dos filhos }\end{array}$ & $\begin{array}{l}\text { Quarto casal, } \\
\text { sala }\end{array}$ & $\begin{array}{l}\text { Cozinha, quarto, } \\
\text { sala }\end{array}$ & $\begin{array}{l}\text { Sala/quarto, } \\
\text { cozinha }\end{array}$ & $\begin{array}{l}\text { Varanda } \\
\text { posterior, sala }\end{array}$ & Cozinha \\
\hline & $\begin{array}{l}\text { Espaços mais } \\
\text { valorizados pela } \\
\text { família }\end{array}$ & $\begin{array}{l}\text { Buffet, quintal, } \\
\text { quartos }\end{array}$ & Quartos, sala & $\begin{array}{l}\text { Quintal, cozinha, } \\
\text { quarto, sala }\end{array}$ & $\begin{array}{l}\text { Sala/quarto, } \\
\text { cozinha, quarto }\end{array}$ & $\begin{array}{l}\text { Quintal, cozinha, } \\
\text { sala }\end{array}$ & Quarto de casal \\
\hline & $\begin{array}{l}\text { Qualidade } \\
\text { espaciais mais } \\
\text { valorizadas pela } \\
\text { família }\end{array}$ & $\begin{array}{l}\text { Territorialidade, } \\
\text { privacidade, } \\
\text { apropriação do } \\
\text { espaço (buffet) }\end{array}$ & Territorialidade & $\begin{array}{l}\text { Segurança } \\
\text { pessoal e } \\
\text { patrimonial, } \\
\text { apropriação do } \\
\text { espaço }\end{array}$ & $\begin{array}{l}\text { Amplitude dos } \\
\text { cômodos, } \\
\text { segurança } \\
\text { patrimonial, } \\
\text { apropriação do } \\
\text { espaço }\end{array}$ & $\begin{array}{l}\text { Privacidade, } \\
\text { segurança } \\
\text { pessoal }\end{array}$ & $\begin{array}{l}\text { Segurança } \\
\text { pessoal e } \\
\text { patrimonial, } \\
\text { apropriação do } \\
\text { espaço }\end{array}$ \\
\hline
\end{tabular}

Tabela 5: Síntese das informações obtidas a partir da categoria "Modos de Habitar - Dimensão simbólica". Fonte: Elaborada pela autora, 2016.
Identificou-se o desenvolvimento de atividades produtivas em três residências, tanto no interior quanto na parte externa. No caso da moradia A, o morador realizou a construção de um espaço amplo e anexo à residência para o desenvolvimento de negócio próprio - o buffet. Na moradia E, a moradora utiliza constantemente a cozinha da casa para o preparo de artigos alimentícios para venda. Já na moradia $D$, o terreno vizinho à residência, adquirido pela família, é utilizado para o cultivo de mudas de café pelo morador, que trabalha como lavrador em terras arrendadas.

Em relação ao mobiliário presente nas residências, em algumas moradias as condições de conservação de móveis são precárias, havendo uma constante improvisação e reaproveitamento de material de refugo para repará-los, demonstrando a situação de indisponibilidade financeira dos moradores. Contudo, em relação aos equipamentos eletrônicos e eletrodomésticos, paradoxalmente verificou-se a presença de equipamentos de última geração, como TVs de tela plana e vídeo games, utilizados principalmente por moradores adolescentes e jovens, em contraste com as condições construtivas precárias da residência e do mobiliário.

\section{b. Dimensão simbólica}

Os aspectos simbólicos mais relevantes se diferem entre as moradias. A territorialidade está presente principalmente em residências onde há presença de filhos adolescentes. A demarcação de limites entre público e privado é uma constante em todas as moradias, pela presença de muros ou cercas, relacionados também com a segurança pessoal e patrimonial. A apropriação do espaço é recorrente, pela presença de objetos funcionais ou simbólicos e pela afetividade referida a alguns ambientes.

\section{c. Dimensão temporal}

A dimensão temporal é percebida principalmente pelas ampliações realizadas nas moradias, em elevado número na maioria dos casos. Verifica-se que as primeiras ampliações são feitas horizontalmente, sendo posteriormente realizadas no sentido vertical, quando a estrutura da construção permite ou foi prevista para este fim. Dos três casos em que houve ampliação vertical, dois deles possuem terraços cobertos com estrutura e telhas metálicas. 


\begin{tabular}{|c|c|c|c|c|c|}
\hline $\begin{array}{l}\text { MORADIA / } \\
\text { VARIÁVEIS }\end{array}$ & $\begin{array}{l}\text { Ampliações } \\
\text { realizadas }\end{array}$ & Sentido de ampliação & $\begin{array}{l}\text { Etapas de } \\
\text { construção da } \\
\text { moradia }\end{array}$ & $\begin{array}{l}\text { Fatores de } \\
\text { influência no } \\
\text { projeto da } \\
\text { construção ou } \\
\text { ampliação }\end{array}$ & $\begin{array}{l}\text { Motivação para } \\
\text { ampliações }\end{array}$ \\
\hline $\begin{array}{l}\frac{\pi}{4} \\
\frac{1}{0} \\
\frac{1}{\alpha} \\
0 \\
\frac{1}{\Sigma}\end{array}$ & 4 & & $\begin{array}{c}\text { Casa doada } \\
+1 \text { quarto, cozinha, } \\
\text { varanda frontal e } \\
\text { varanda posterior } \\
+ \text { Buffet } \\
+ \text { Ampliação do buffet }\end{array}$ & $\begin{array}{l}\text { Projeto de ampliação } \\
\text { (Projeto Habitat), } \\
\text { conhecimento técnico } \\
\text { do } \\
\text { morador/construtor, } \\
\text { construção em } \\
\text { terreno vizinho }\end{array}$ & $\begin{array}{l}\text { Número de filhos, } \\
\text { atividade } \\
\text { produtiva em } \\
\text { casa }\end{array}$ \\
\hline 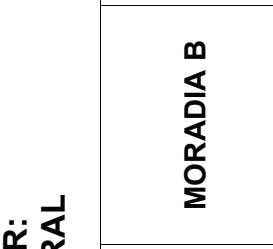 & 2 & & $\begin{array}{c}\text { "Barraquinho" } \\
\text { + Quarto na casa } \\
\text { existente } \\
\text { + Quarto/sala/cozinha, } \\
\text { banheiro } \\
\text { + Quarto de casal, } \\
\text { sala/cozinha, área de } \\
\text { serviço/cozinha } \\
\end{array}$ & $\begin{array}{l}\text { Conhecimento } \\
\text { técnico do } \\
\text { morador/construtor }\end{array}$ & $\begin{array}{l}\text { Separação do } \\
\text { quarto da } \\
\text { cozinha, quarto } \\
\text { para os filhos, } \\
\text { aproveitar o } \\
\text { material doado } \\
\text { pela prefeitura }\end{array}$ \\
\hline 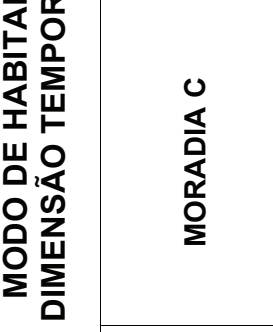 & 6 & & $\begin{array}{c}\text { "Barraquinho" } \\
+3 \text { quartos, sala, } \\
\text { cozinha, copa, } \\
\text { banheiro } \\
\text { + Varanda frontal, } \\
\text { garagem, varanda } \\
\text { posterior } \\
\text { + Terraço } \\
\text { + Moradia no } 1^{\circ} \\
\text { pavimento } \\
\text { + Terraço }\end{array}$ & $\begin{array}{l}\text { Conhecimento } \\
\text { técnico dos pedreiros }\end{array}$ & $\begin{array}{c}\text { Construção de } \\
\text { área de serviço } \\
\text { coberta e fogão a } \\
\text { lenha, solucionar } \\
\text { o problema de } \\
\text { infiltração na laje, } \\
\text { moradia para } \\
\text { família de um dos } \\
\text { filhos }\end{array}$ \\
\hline 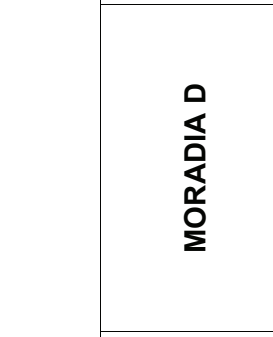 & 5 & & $\begin{array}{c}\text { "Barraquinho" } \\
\text { + Cozinha/quarto e } \\
\text { banheiro } \\
+ \text { Quarto, sala } \\
\text { + Cozinha, banheiro, } 2 \\
\text { quartos, varanda } \\
+ \text { Cômodos para } \\
\text { aluguel } \\
+2 \text { moradias no } 1^{\circ} \\
\text { pavimento }\end{array}$ & $\begin{array}{l}\text { Conhecimento } \\
\text { técnico do } \\
\text { morador/construtor, } \\
\text { projeto de ampliação } \\
\text { (Projeto Habitat) }\end{array}$ & $\begin{array}{c}\text { Cômodos } \\
\text { amplos, obter } \\
\text { renda através de } \\
\text { aluguel, } \\
\text { solucionar } \\
\text { problemas de } \\
\text { infiltração na laje, } \\
\text { herança para os } \\
\text { filhos, mudança } \\
\text { para o primeiro } \\
\text { pavimento } \\
\end{array}$ \\
\hline 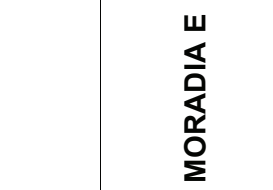 & 3 & & $\begin{array}{c}\text { Cozinha, sala/quarto, } \\
\text { banheiro } \\
+2 \text { quartos, sala, } \\
\text { cozinha, banheiro } \\
+ \text { Varanda posterior }\end{array}$ & $\begin{array}{c}\text { Influência do } \\
\text { pedreiro, projeto de } \\
\text { ampliação (Projeto } \\
\text { Habitat) }\end{array}$ & $\begin{array}{l}\text { Quartos para os } \\
\text { filhos }\end{array}$ \\
\hline 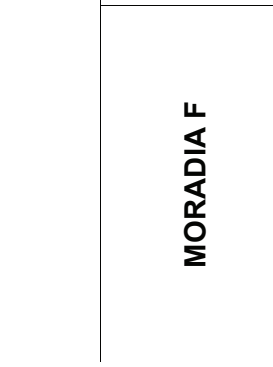 & 3 & & $\begin{array}{l}3 \text { quartos, sala, } \\
\text { cozinha, banheiro } \\
\text { + Depósito, área de } \\
\text { serviço, banheiro } \\
\text { + Moradia no } 1^{\circ} \\
\text { pavimento } \\
+ \text { Terraço }\end{array}$ & $\begin{array}{l}\text { Conhecimento } \\
\text { técnico dos pedreiros }\end{array}$ & $\begin{array}{c}\text { Ampliar o quarto } \\
\text { do casal, } \\
\text { construção da } \\
\text { área de serviço } \\
\text { externa, } \\
\text { solucionar } \\
\text { problemas de } \\
\text { infiltração na laje, } \\
\text { herança para os } \\
\text { filhos, mudança } \\
\text { para o primeiro } \\
\text { pavimento }\end{array}$ \\
\hline
\end{tabular}

Tabela 6: Síntese das informações obtidas a partir da categoria "Modos de Habitar - Dimensão temporal". Fonte: Elaborada pela autora, 2016. 
A construção inicial de algumas moradias foi referida pelos moradores como "barraquinho", denotando sua provisoriedade como condição para se satisfazer as primeiras necessidades habitacionais de abrigo e segurança. Estas condições permitem que se prossiga para a satisfação de níveis superiores de necessidades, conforme a relação feita por Leite (2006) entre a pirâmide de necessidades de Maslow (1954) e as necessidades habitacionais satisfeitas por etapas na moradia.

Nos diálogos com os moradores, constatou-se que as obras foram influenciadas pelo conhecimento técnico dos pedreiros ou de moradores que possuíam experiência em construção civil. Em alguns casos em que houve envolvimento do Projeto Habitat, o planejamento e as orientações técnicas foram levadas em consideração. As motivações relatadas para as ampliações e reformas se davam principalmente pela necessidade de quartos para os filhos, pois, em alguns casos, os quartos antigos eram compartilhados por toda a família ou por vários filhos. Nos casos em que houve ampliação vertical, esta foi relatada como forma de solucionar problemas com infiltrações, através da construção de lajes de concreto armado.

\section{Considerações finais}

A reflexão aqui empreendida contribui para o estudo de espaços domésticos autoconstruídos pela população de baixa renda. Do ponto de vista da formação arquitetônica, pode-se afirmar que o espaço autoconstruído é pouco debatido, geralmente caracterizado como esteticamente caótico, construtivamente precário e urbanisticamente irregular/ilegal. Contudo, a realidade socioeconômica e urbanística das cidades brasileiras necessita de novos olhares e formas de intervenção por parte de profissionais que se dediquem a questões condizentes com a realidade da maioria da população.

Certas descobertas feitas durante o estudo levam à reflexão sobre o fazer arquitetônico em HIS. O desenvolvimento de atividades produtivas nas residências pode ser considerado como variável para se repensar o projeto da moradia, uma vez que contribui para a superação de restrições econômicas. Nesse sentido, pode ser interessante que o projeto arquitetônico de HIS forneça espaços ou possiblidade de flexibilização ou ampliação de cômodos para o desenvolvimento de atividades produtivas ou de serviços.

Outra contribuição se dá em face da representação da casa como um projeto de vida, como constituição de um patrimônio familiar e suporte econômico e social para os descendentes. Estas representações se materializam na prática da construção incremental, em que o fator temporal é relevante. Acredita-se que o projeto participativo e o processo de construção incremental podem ser incorporados ao projeto arquitetônico, permitindo que a casa seja ampliada de acordo com o desenvolvimento econômico da família e proporcionando melhor apropriação do espaço residencial e satisfação com a moradia.

Observou-se que diversas dificuldades nas obras das residências poderiam ser sanadas com orientação técnica e planejamento mais minucioso das etapas construtivas. Nesse sentido, a assessoria técnica mediante a viabilização e operacionalização da Lei Federal 11.888/08 auxiliará as famílias no seu planejamento para o alcance mais eficaz da satisfação residencial. 
Espera-se que as reflexões realizadas neste estudo tragam luz ao debate sobre a autoconstrução e as formas de provisão habitacional nas cidades brasileiras. Aponta-se a necessidade de outras investigações sobre a autoconstrução explorando contextos distintos. Grande parte da população brasileira tem na autoconstrução a principal forma de acesso à moradia, não se restringindo apenas à população com a menor faixa de renda. Sendo assim, a investigação em contextos onde as restrições econômicas são menores, por exemplo, se faz necessária, uma vez que muitas pessoas não contratam profissionais habilitados para o planejamento e acompanhamento de obras, seja pelo desconhecimento de suas atribuições ou pela burocracia e gastos que eles representam, em seu imaginário.

\section{Referências bilbiográficas}

ABREU, M. G.; METELLO, H. S., YUBA, A. N. Habitação de interesse social no Brasil: caracterização da produção acadêmica dos programas de pós-graduação de 2006 a 2010. Arquitextos, São Paulo, ano 15, n.178.03, Vitruvius, mar. 2015. Disponível em: <http://www.vitruvius. com.br/revistas/read/arquitextos/15.178/5495>.

ALGRANTI, L. M. Famílias e vida doméstica. In: SOUZA, L. M. (Org.) História da vida privada no Brasil: cotidiano e vida privada na América Portuguesa. São Paulo: Companhia das Letras, 1997. p. 84-154.

BARBETTA, P. A. Estatística aplicada às ciências sociais. Florianópolis: Ed: UFSC, 2011.

BOMFIM, Z. Á. Afetividade e Ambiente Urbano: Uma proposta metodológica pelos mapas afetivos. In: PINHEIRO, J. Q; GUNTHER, H. (Orgs.). Métodos de Pesquisa nos Estudos Pessoa-Ambiente. São Paulo: Casa do Psicólogo, 2008.

CARDOSO, A. L. (Org.) O Programa Minha Casa Minha Vida e seus efeitos territoriais. Rio de Janeiro: Letra Capital, 2013.

CARVALHO, A. W. B. et al. A assistência técnica gratuita para o projeto de habitação de interesse social: Uma Experiência de Aproximação Entre Pesquisa, Ensino e Extensão. In: VI Projetar, 2013, Anais...Salvador: UFBA, 2013.

COELHO, D. D. Da fazenda ao bairro: A construção de uma Nova Viçosa (1970-2000). 2013. Monografia (Graduação em Geografia) - Departamento de Geografia, Universidade Federal de Viçosa, Viçosa, 2013.

CRUZ, T. A. et al. (Coord.) Retrato social de Viçosa V. Viçosa: CENSUS, 2014.

DIAS, A. L. N. et al. Estudo comparativo do processo de ocupação irregular do solo urbano nas áreas centrais e periféricas. Relatório Final de Pesquisa. Viçosa: PIBIC/CNPQ/DAU/UFV, 2011.

ELALI, G. A.; PINHEIRO, J. Q. Analisando a experiência do habitar: algumas estratégias metodológicas. In: VILLA, S. B., ORNSTEIN, S. W. (orgs.). Qualidade Ambiental na Habitação: avaliação pós-ocupação. São Paulo: Oficina de Textos, 2013.

GUERRA, I. Modos de vida: novos percursos e novos conceitos. Sociologia - Problemas e Práticas, Lisboa, n.13, p. 59-74, 1993.

LAGO, L. C. (Org.) Autogestão habitacional no Brasil: utopias e contradições. Rio de Janeiro: Letra Capital, 2012.

LEITE, L. C. R. Avaliação de projetos habitacionais: determinando a funcionalidade da moradia social. São Paulo: Ensino Profissional, 2006.

LEMOS, C. A. C. História da casa brasileira. São Paulo: Editora Contexto, 1989. 
LOBO, E. S. Caminhos da sociologia no Brasil: modos de vida e experiência. Tempo social. São Paulo, USP, n.4 (1-2), p.7-15, 1992

MASLOW, A. H. Motivation and personality. New York: Harper \& Brothers, 1954.

NABARRO, S. A. Modo de vida e campesinato no capitalismo: contribuições, limites e a construção de um entendimento do campesinato como modo de vida. 2014. Tese (Doutorado em Geografia Humana) - Faculdade de Filosofia, Letras e Ciências Humanas da Universidade de São Paulo, São Paulo, 2014.

NASCIMENTO, D. M. A autoconstrução na produção do espaço urbano. In: MENDONÇA, J. G.; COSTA, H. S. M. (orgs) Estado e capital imobiliário: convergências atuais na produção do espaço urbano brasileiro. Belo Horizonte: Ed. C/Arte, 2011, p. 217-230.

PEREIRA, S. M. Casa e mudança social: uma leitura das transformações da sociedade portuguesa a partir da casa. Lisboa: Caleidoscópio, 2012.

PINHEIRO, A. P. S. C. Modo de olhar. Metodologia para o estudo de moradias rurais. Dissertação (Mestrado em Estruturas e Construção Civil) - Universidade Federal do Ceará, Centro de Tecnologia, Fortaleza, 2011.

PINTO, T. C. Modelos de habitat, modos de habitar: o caso da construção clandestina do habitat. Sociedade e território - Revista de estudos urbanos e regionais. Lisboa: Edições Afrontamento, fev. 1998. n. 25/26, p. 32-44

RHEINGANTZ, P. A. et al. Observando a qualidade do lugar. procedimentos para o trabalho de campo. Rio de Janeiro: FAU, UFRJ, 2009.

VIDAL, T.; POL, E. La apropiación del espacio: una propuesta teórica para comprender la vinculación entre las personas y los lugares. Anuario de psicologia, Barcelona: Universitat de Barcelona, Facultat de Psicologia, v. 36, n. 3, p. 281-298, dez. 2005.

VILLA, S. B., ORNSTEN, S. W. Qualidade ambiental na habitação: avaliação pós-ocupação. São Paulo: Oficina de textos, 2013. 